\title{
THE HARD WORK OF SMALL TALK IN ETHNOGRAPHIC FIELDWORK
}

\author{
Henk Driessen \\ Cultural Anthropology and Development Sociology, Radboud University Nijmegen, \\ The Netherlands. Email: h.driessen@maw.ru.nl \\ Willy Jansen \\ Institute for Gender Studies, Radboud University Nijmegen, The Netherlands. \\ Email: w.jansen@maw.ru.nl
}

KEY WORDS: Small talk, Phatic communion, Ethnographic fieldwork, Research techniques, Craftsmanship, Research training

In this article we explore the importance of small talk in the context of ethnographic fieldwork. Our examples derive from more than thirty years of research experience in Spain, Morocco, Algeria, Jordan, and The Netherlands. We argue that small talk is a central, yet taken-for-granted, ingredient of ethnographic fieldwork. We claim that this skill should be reflected upon and given a more consistent role in supplementing and correcting data obtained by other techniques. It is our conviction that it can and should be taught in courses on research methods and techniques.

RECENT BOOKS ON ETHNOGRAPHY pay attention to the wealth of fieldwork practices past and present - among many other features, to edginess, ambiguity, agony, risk, adventure, boredom, friendship, sexuality, distance and involvement, midcareer field site shifts, and suspense (Borneman and Hammoudi 2009; Driessen 2013; Faubion and Marcus 2009; Gottlieb 2012; Robben and Sluka 2007). Yet, they rarely take into systematic account what we call the hard work of small talk, which we consider to be the hidden core as well as the engine of ethnographic research, whether "at home"" or "abroad."

We argue on the basis of our own field experiences and those of many colleagues with whom we have talked over the years, often on the margins of conferences and meetings, that the art of making small talk, in daily life a basic social skill, is an important if not central ingredient of working in the field. It belongs to the systematic "hanging around" which still is the core of fieldwork in spite of recent changes in fieldwork practices (Geertz 1998). ${ }^{1}$ Making small talk is in our view and experience far more important in terms of the production of field notes than doing interviews, although there is a thin and fluid boundary between open and informal interviews and small talk.

In this article we explore what the hard work of making small talk actually means in the context of doing ethnographic fieldwork. The examples we evoke cover more than thirty years of our research experience in different places, but mainly in Spain, Morocco, Algeria, Jordan, and The Netherlands. We argue that it can be taught in tandem with other techniques, such as interviews, focus group 
discussions, or the use of digital media (see Lee 2003), and that systematic attention should be paid to it in courses on research methods and techniques. Moreover, we claim that this tool should be reflected upon and given a more consistent role in triangulation and in correcting the data obtained by other techniques. We see it as the central feature of what George Marcus recently called the "culture of craftsmanship" (Marcus 2009:3) and will therefore discuss how it can help in ethnographic fieldwork and how it can be taught. Among other things, small talk helps to establish, maintain, and expand the network of interlocutors. More importantly, it provides access to information that is difficult to get otherwise and could be central to understanding the local culture.

\section{SMALL TALK AND PHATIC COMMUNION}

What precisely does "small talk" mean? According to the Oxford English Dictionary it is light talk or conversation, chit-chat and gossip. The OED lemma quotes from a 1751 letter by the Earl of Chesterfield, who saw the engagement in small talk as "the general run of conversation in most mixed companies." Small talk has often been categorized as irrelevant talk and its main function interpreted as the avoidance of silence. In the 1950s and 1960s, a few scholars of the ethnography of speaking did provide insights that are relevant to understanding the importance of small talk for anthropological fieldwork (Frake 1964; Goffman 1990; Gumperz and Hymes 1964; Hymes 1962).

It was Bronislaw Malinowski who in 1923 introduced the concept of phatic communion as part of the anthropological toolkit. He defined it as "a type of speech in which ties of union are created by a mere exchange of words . . . establishing bonds of personal union between people . . . bringing them into the pleasant atmosphere of polite, social intercourse" (Malinowski 1946:315-16). He held that language in phatic communion is not an instrument of reflection but a mode of interaction. Although Malinowski was at the cradle of the twentiethcentury fieldwork canon, he never applied his concept of phatic communion to the practice of doing ethnographic fieldwork. Establishing such communion or "rapport," as it was also called, is a crucial phase in ethnographic research. The success of fieldwork depends to a large extent on the ability to establish, develop, and maintain good relationships with interlocutors (Sluka 2007:121). Small talk plays a crucial role in this process.

Recently, small talk has been studied more seriously and systematically in sociolinguistics. It is now being seen as too limiting to equate small talk with everyday conversation. In spite of its apparent superficiality and casualness, it is increasingly being seen as functionally multifaceted; central to social interaction, both ritualized and informal; and having direct relevance to transactional and institutional goals (Boxer 2011; Coupland 2000; Holmes 2005).

We do not know of any attempts so far to apply recent insights on small talk to the practice and context of ethnographic fieldwork. Although many anthropologists are aware of the importance of informal conversation, they have rarely paid serious and systematic attention to it. One of the few exceptions is a 
brief article by a French ethnographer on "floating observation"-in fact closely related to small talk - by which she meant keeping oneself responsive and not focusing attention on any specific object. In other words, being receptive by hanging around in specific places and developing sensitivity to chance encounters in which people reveal their local or inside knowledge (Pétonnet 1982). More recently, Judith Okely (2010), who discussed fieldwork in psychoanalytic terms as free association and free passage, also came close to our understanding of the roles of small talk. ${ }^{2}$

Why the lack of systematic attention paid to this central aspect of fieldwork in both teaching and writing? Relative to interviewing, on which there are shelves of guides and books, small talk has mostly been taken for granted. Probably one of the reasons is that its vaguely defined nature does not fit the dominant rhetoric of control, planning, and structuring in social science methodology. It questions current notions of validity and replication, and it tends to escape formalized training in research methods.

A second reason may be that small talk and the related, unobtrusive "fly on the wall" stance of the fieldworker are at loggerheads with informed consent ethics. The negative feelings surrounding gossip make it difficult for anthropologists to confess that most of their best insights into hierarchies, social conflicts, or people's experiences are obtained through participating in or overhearing gossip. To be sure, there are indeed ethical problems that have to be resolved (Bernard 1995:347-59; Borofski 2005:15-17, 61-63; Peacock 1986:62-63). ${ }^{3}$ We hold that potential interlocutors should indeed be informed about the fieldworker's goals, but we do not think it necessary from an ethical point of view to constantly repeat the research intentions during small talk and daily communication. Gossip may be only a sub-genre of informal talk in general that should not present an ethical problem in fieldwork as long as interlocutors know that they are dealing with a researcher (Driessen 1998).

A third reason may be the common conflation of qualitative interviews with doing ethnographic fieldwork. Both are indeed qualitative research techniques, but they are different. The results of a two-hour interview with a woman are different from those of daily chats while living in her house for six months; that such kitchen-table talk is perfectly suitable for social analysis was aptly illustrated by Gullestad (2002). This conflation is related to the reduction of time spent on qualitative research. Increasingly, research has to be done in shorter time periods, leading to how-to books such as Finding out Fast (Thomas, Chataway, and Wuyts 1998). Such work rests on what we call a hurried and rudimentary veni vidi vici strategy. John Van Maanen (2011:164) recently referred to it as Blitzkrieg fieldwork: "Formal interviews, sample surveys, focus groups, brief periods of observation . . . replace lengthy in situ immersion." Ulf Hannerz called the work of the foreign correspondents he studied "parachute anthropology." Although we are aware of the increased pace of research and the shrinking of resources, this is not ethnographic fieldwork in the strict sense of the term. A prerequisite of making small talk is that one knows the language and has had the time to learn local expressions. The increased use of paid interpreters in pruned undergraduate 
and sometimes even postgraduate fieldwork runs counter to this precondition. Using interpreters in fact means being completely cut off from the benefits of participation in small talk exchanges, apart from being entirely dependent on the willingness and ability of a mediator to translate statements in as precise and detailed a fashion as possible.

Apart from the embarrassment of not speaking the language, a final reason for underestimating and devaluing this aspect of fieldwork may be that the ability to participate in small talk is a part of human sociability in which anthropologists are not equally well-versed. In a sense, this social grace seems a "natural" gift which one simply has or lacks. Yet, it is our view that it can and must be taught as part of ethnography's "culture of craftsmanship." We formulate a program below after illustrating, from our own fieldwork experiences, why making small talk is important.

\section{THE RELEVANCE OF SMALL TALK IN FIELDWORK}

Until the 1950s, "the field" was mostly conceived as a more or less enclosed entity, a tribe or village, a site that a fieldworker could get to know by engaging with locals face to face. "Being there" for at least a full annual cycle was generally considered the main avenue to sound ethnographic knowledge (Geertz 1988). Since the 1980s, the vast majority of anthropologists are very much aware of the fact that hard and fast boundaries around "a culture" in "the field" is an illusion detrimental to the development of the discipline. Instead of being fixed "isolates," "field sites" in an ethnographic sense are now generally considered rather fluid entities, both in terms of time and space, interconnected to wider fields in myriad ways (Augé and Colleyn 2006:81-82, 94; Hannerz 2010:59). One of the main citations for this shift is the article on multisited ethnography in which Marcus (1995:96) encouraged fieldworkers to move away from "singlesite designs" toward mapping "the circulation of cultural meanings, objects and identities in diffuse time-space." This seminal article can be seen as an early plea to make social science research more dynamic and sensitive to mobility and connectivity.

Engaging in small talk in the widest sense of the term, nonverbal behavior included, has a crucial connective function in this fluid and mobile world. People connect by looking, smiling, exchanging words, making connective gestures, and other micro-interactional forms. This connection facilitates the establishment of what in the early literature on fieldwork was called "rapport," the overcoming of strangeness, newness, and otherness by multisensory and multilayered exchange as a means to bridge the personal and cultural divide. Small talk is a necessary lubricant not only between the researcher and research participants but also in facilitating access to a wider network.

Connecting as humans is obviously the precondition for further contact. More important, however, is that it may yield access to what really matters. The most poignant quotes and salient details about a person or phenomenon emerge from small talk or in its aftermath, and these may be crucial for a "thick description" of 
social or cultural details. It may provide "backstage" information that is difficult to elicit otherwise (Goffman 1990:114). The underlying tensions, hierarchies, and past and present conflicts in the community or network under study may be hinted at in small talk, and this will help to sensitize the fieldworker's perceptivity. Asking too many and too straightforward questions, in particular at the beginning of fieldwork, may be detrimental. The drawbacks of direct questioning in the interview format are obvious. Such questions often contain preconceived ideas and cultural schemes, unintentionally introduce hierarchy in the relationship between fieldworker and interlocutor, provoke defensive reactions or politically and socially correct answers, yield ethnographic information cut off from the context, and finally, straightforward questions may be perceived as intimidating and abusive (see Blok 2000; O'Dell and Willim 2011). There has to be some cultural context from which questions emerge and within which answers can be interpreted. This context will slowly emerge from the patient and hard work of small talk.

Moreover, sensitivity to small talk provides ample space for serendipity, which plays a much more important — even critical — role in social science research than most methodologists would admit (Blok 2005; Geertz 2000; Merton and Barber 2004). It can sensitize the researcher to unexpected categories, topics, and viewpoints. Rather than seeing "interviews" and "small talk" as distinct modes of gathering information, we prefer to view them on a continuum of communion between the fieldworker and interlocutors. Small talk is even an inevitable ingredient of a structured interview as it is part of the introductory process and a way to open up communication between researcher and respondent.

Our own research experiences in Spain, Morocco, Algeria, and Jordan provide many examples of the importance of small talk and its heuristic function in doing fieldwork. In Spain it was mainly through small talk-for example, by paying attention to nicknames, abbreviations, or covert language being used-that we could discover the tensions and hierarchies that were kept in the background. It was only after months of small talk with a variety of interlocutors that fragments of the taboo subject of the Spanish Civil War and its traumatic aftermath emerged during fieldwork in a village and town in Andalusia (Driessen 2013). Only after long hours of socializing and participation in family affairs did we learn that the Socialist grandfather of a key informant who was the town's mayor in 1936 was shot summarily in October 1936. This painful fact turned out to be important for understanding the local political relationships during the transition period to democracy between 1976 and 1986.

Returning to Spain in the spring of 2010, 2011, and 2012 to conduct shortterm fieldwork in Málaga on the escalation of Holy Week celebrations, we made ample use of small talk with participants in the processions and onlookers along the streets to unravel the complexities of the pageants. We continued doing so after the officially announced processions were finished, and by chance we "discovered" elaborate secondary rituals in which a remarkable gender reversal took place. If we had not stopped to talk with a small group of people apparently waiting for something, we would have completely missed these ritual closures (Driessen and Jansen 2013). Moreover, it gave a new twist to the gender changes 
and the increased participation of women that we had documented in another paper (Jansen and Driessen 2013). This was probably the main "reward" for going through an exhausting week of fieldwork. We are convinced that many colleagues must have had similar experiences of discovering unexpected data before and after the planned period of observation and interviewing.

It took five months of intensive small talk and socializing to find out how the intricacies of interethnic politics worked in the Spanish enclave of Melilla on the northern Moroccan coast (Driessen 1992). Driessen found out that the institution of agasajo (banquet, an ethnically mixed gathering among the members of the upper class) and the ethos of convivencia (the desired and propagated peaceful coexistence of Christians, Muslims, Jews, and Hindus) played a focal role in interethnic accommodation among the local elites. Patience and discipline, and self-sacrifice, the "hard work" in the current article's title, were indispensable for gaining this insight.

Sometimes, small talk may lead to quicker access to taboo subjects. In Algeria, abortion was forbidden and was therefore a topic to be avoided in formal interviews, but by casually discussing the various herbs women were growing in pots in their courtyard, Jansen soon discovered how women used some plants to induce an abortion (Jansen 1987:147).

Furthermore, through small talk the anthropologist learns the local ways of talking about and dealing with local phenomena (Geertz 1983). It is a necessary stage to learn the proper words and style for in-depth and confidential interviewing because through learning the words or their specific meanings one understands the sensitivities in a culture. When Jansen began her fieldwork in Algeria and was struggling with the local Arabic, she used photographs of her family to start conversations. The children were fascinated with these family pictures and quickly taught her the cultural hierarchy of love by booing when she pointed out the "wrong" person in answer to their question about whom she loved most. Moreover, they quickly changed the word "friend" into "fiance" because in their perception a male friend could never be in the same picture with an unmarried girl, and therefore they assumed he was her patrilineal parallel cousin (the preferred mate in this culture).

This last example shows the importance of small talk not only for accessing cultural meanings but also for enlarging one's network of respondents. It is crucial to make small talk with groups who are not necessarily targeted for interviews but who may confirm, diversify, or refute cultural information gathered elsewhere. Children can be excellent informants as well as perfect subjects of small talk because they are central to people's personal lives. Before our daughter (aged four) arrived in Jordan, our host family predicted that she would be afraid of greeting the grandmother because of her wrinkled and tattooed face. But when she unhesitatingly kissed the sweet lady she was immediately cherished. Less self-conscious than adult fieldworkers, she had copied the right body language, thus making a great contribution to our small talk.

Practicing a newly learned language in the field during small talk, with all the mistakes it involves, can also provide moments of relaxation and laughter. 
Thirty years after our first stay in a small Spanish town our former neighbors still recalled that Jansen had used the word buco rather than cubo. Our mistaking a pail for a billygoat was a running joke. Since humor and joking are recurring elements of socializing, and can be very informative about social hierarchies and sensitivities, learning to understand the pun is part of good fieldwork. For Jansen, it was crucial to be able to see the social critique on Algerian food economics in cartoons and comic strips (Jansen 2001).

Small talk not only smoothens interpersonal contacts and increases relevant data, it can also lead to theoretical reconsiderations. Driessen (1983) used numerous instances of small talk and floating observation in male exchanges in bars to develop his ideas on ritualized masculinity at a time when gender studies in cultural anthropology were still predominantly women's studies. His argument was also shaped by the small talk Jansen had with female neighbors during their social visits with other women and their verbal exchanges in the marketplace. The masculinity idea was pushed into the right direction by our own conversations about our experiences of single-sex exchanges in the streets and bars of the Andalusian town where we conducted ethnographic fieldwork. This example shows how small talk at three interrelated levels-fieldwork, evidence, and theory-helped to shape the development of a specific argument about the nature of gender relationships, in particular with reference to male sociability and rites of masculinity. To put it somewhat bluntly: there can be no fieldwork relations, evidence, or insightful learning without small talk.

\section{HARD WORK}

Colleagues from other disciplines and faculty administrators sometimes see ethnographic fieldwork as paid holidays in exotic places-in our case, on the Mediterranean. They fail to understand that it can be serious and demanding work. Most anthropologists know the physical and mental stress of working in the field. During field research in Spain in the 1970s, we experienced the realities of life in an agricultural community. Small talk played an important role during hard manual and collective labor in the field, in which large numbers of day laborers were involved. In the mixed-gender work gangs for the olive, grape, and cotton harvests, the making of small talk, which also included joking and singing, was ritualized during both the actual work and the breaks. It served as an antidote to the backbreaking and monotonous nature of agricultural tasks (Driessen 1983). Active participant observation in this work allowed us to feel, if only for a few days, how much one's back or hands can hurt as well as what the laborers thought about their employers.

We do not mean to imply that small talk is as difficult as agricultural work. Ethnographic fieldwork is of course primarily labor of the mind rather than the body. Nonetheless, it is an intense and tiring activity in which the body and its senses are mostly fully involved - in two words, "sensuous ethnography" (Stoller 2009:74-76). Adaptation to a different climate, time rhythm, and food pattern or health regime can in itself have bodily consequences. But this is reinforced 
when submerging and participating in another culture and society while trying to understand what is going on. When one is eager to observe what people are doing during the day, one may easily forget that a warmer climate requires a siesta after lunch. Adjusting to a cultural rhythm in which important events occur at times one would normally be sleeping at home also takes its toll. Fieldworkers must adapt their own schedule to that of the researched and come to terms with their own tiredness. Much of their data will be the result of "productive fatigue." Jansen experienced how rewarding it can be to ignore one's body's signals of fatigue when she attended a wedding party in a provincial capital in Algeria. Because she was very close to the bride and her family, she decided to hang on a little longer and help clean up, rather than leave with most of the guests. Jansen was still fighting sleep when suddenly the music changed to trance rhythms. Previously, respondents had insisted that possession rituals had disappeared in urban contexts and were merely remnants of saint cults in rural areas. But it turned out that this was merely a socially acceptable or politically correct response in a context of elite disapproval of possession cults. In fact, the musicians, hosts, and remaining wedding guests used this occasion for a long night of trance dancing. Had she listened to her personal bodily rhythm, she would never have known that the practice was still very much alive in the privacy of home (Jansen 1987:91-104).

Some problems seem to be almost universal among fieldworkers, particularly those related to eating, bathing, sleeping, lack of privacy, and loneliness (Kulick 1992:268-75). Lack of sleep is a recurring feature of doing fieldwork. An anthropologist works in the field almost around the clock; there is little time for rest. As in agriculture, "the field" is always there. So are the field notes that need to be written right about the time one is ready to fall asleep. Dreaming is partly a continuation of fieldwork which, indeed, is hard work.

The need to talk and listen may also lead to overeating. This is partly the result of local hospitality norms, since sharing of food is a central aspect of sociability in many societies. More than once we have had to eat two meals right after each other, when we did not want to disappoint a host who had prepared a table full of food for us. We also know of colleagues who frequently went hungry because they could not or would not eat in front of others who had nothing to eat. But overeating or fasting may also be a reaction to uncertainty and anxiety. Some anthropologists have been known to hide their cache of peanut butter; we indulged in Swiss chocolate in Spain and pastries in Algeria when out of view of our research participants. The eagerness with which locals wanted us to consume alcohol was equally problematic in Spain, where male socializing in bars required the anthropologist to be able to hold a substantial amount of liquor, and in Algeria, where individual policemen or officials wanted to share wine and sex in return for a visa or research permit.

Making small talk in an unfamiliar language is a highly intellectual endeavor that consumes much energy. Joking, double talk, using local counting systems, or hearing whispered gossip all require a constant alertness, intense concentration, and an extensive vocabulary. After fumbling like a child in the new language for a while, it can seem like a great victory when a political cartoon can be 
"read," a joke made elicits laughter, or the double meanings of a wedding song are understood (Driessen 1997; Jansen 1987, 2000). Mental fatigue can be the consequence of constant multitasking. While trying to find the appropriate words and questions, one simultaneously has to memorize whatever is heard, seen, and felt; make mental notes; contextualize the data in order to understand them; and react immediately.

The claims on the fieldworker by those who help inform or see themselves as friends can be felt as breaches of one's privacy and rest time. It may take a while to get used to a different concept of personal space than one is used to. The local Andalusian musicians who decided to perform an aubade in front of our house in return for some drinks were not very welcome when they woke us at three or four in the morning. The recent innovations of fieldwork and digital ethnography, with cell phones, notebooks, and iPads used in the remotest parts of the world and multiple "friends" seeking and expecting instant contact and small talk, are both a blessing for facilitating digital small talk (exchange of tweets) and a curse as they may seriously disturb work and rest.

Like the administrators and fellow scholars from neighboring disciplines at home, informants or interlocutors in the field do not see small talk as hard work. Chatting while washing up, having tea together, hanging around in bars, joining evening strolls, attending a cockfight, or observing midnight processions nowhere counts as serious work. The presentation of oneself as a working person takes place in the field by doing archival work, taking notes, recording interviews, and typing. After long hours of writing, we were always amused when our Algerian landlady or Andalusian neighbor said: "Come on, you worked enough. Let's go and visit some friends." Little did they know that the hardest work of the day for us had just started.

\section{LEARNING TO MAKE AND USE SMALL TALK}

We hold that using small talk for an ethnographic purpose can be taught in tandem with other techniques, such as interviews, content and discourse analysis, focus group discussions, or the use of digital media. The best way to start doing so is by paying attention to it in undergraduate and graduate courses on methods and techniques. Moreover, more reflection should be focused on small talk and it should be given a more consistent role in supplementing and correcting data obtained by other research techniques. ${ }^{5}$

From the above experiences a number of elements can be elicited that should be part of this training. First and foremost an effort must be made to learn the local language. Knowing the language opens hearts and doors. Especially requiring reflection are the facts that words may have different meanings in different contexts or for different people; what people say can differ from what they say later or what they actually do; and such incongruities are not detrimental to a successful research outcome but the very "stuff" of doing fieldwork. The goal of fieldwork lies precisely in understanding this complex fluidity of meanings and the at-times conflicting relationships between, and intersections of, saying and doing. 
Because familiarizing oneself with another language and culture and making integrative small talk takes time, it needs to be explicitly included in the project schedule as well as in the mindset of teachers and students. Even more than in everyday life, presenting oneself as a friendly, likable, safe, and interested person pays off in smooth social communication. Some people have more social graces than others, but with a bit of practice we can all learn to develop the virtues that facilitate social communication and feelings of communion and trust. And by adapting to the cultural setting, these skills will work wonders in the field. Researchers can be trained to control open-contact situations by practicing how to take the initiative to make contact, invite others to speak, be responsive, remain alert, and show interest in or let oneself be guided by the other person. One can practice courtesy, politeness, attentive and disciplined listening, patience, honesty and openness, reciprocity, respectful curiosity, creating a feeling of equality and valuing the other, and other virtues that support good communication. Exchanging niceties can also be done via cell phone, email, or twitter and Facebook accounts. But communicating via new social media also presupposes learning the cultural codes. For instance, the girls in Jansen's Jordanian research would never post a picture of themselves on Facebook. For their public profile they use a picture of a flower or a kitten rather than revealing their own faces. However, they did send engagement photographs to Jansen by email with the unspoken agreement that she would never use them in publications. In other words, developing "communicative competence" (Hymes 1972) is crucial.

Most cultures and languages accommodate this learning process because a considerable part of the phrases used in small talk have been formalized. Many of the standard phrases for greetings, condolences, departures, or to express gratitude or praise can be learned before going to the field.

Since small talk is more than verbal language, the training program should also include observation and imitation of sound level, body language, or spatial distance, so one learns to smile, laugh, and touch in culturally appropriate ways. Most people are very supportive of this learning process and are happy to teach the implicit rules of their culture when asked, for example, how to behave when someone dies, when and how to embrace in a greeting, or how to ask for a drink (Frake 1964).

Two dangers are involved in such an approach. The first is that by learning the social graces as a technique, or a series of tricks, their "naturalness" may be lost and thus they may not be convincing. The best schmooze is the one that comes naturally and is unpracticed. The second danger is that close communion with some persons may involve the researcher in a web of prejudice and malicious gossip. This can be countered by allowing for a large degree of personal variation and inventiveness, and by conducting this method, like the other methods in social science research, in a controlled, systematic, and reflective way.

To systematically create opportunities for small talk, we suggest a purposive free-floating discovery of place, time, topic, and people, prior to choosing a focus as well as during and after it. In such ethnography, one does not immediately focus on a specific place but purposively encircles it with a mind open to seeing 
other potential places. For instance, when studying prayer, a good locale would be a church or a mosque, but by talking and walking around one might discover that people pray on the beach, along the road, or when admiring a beautiful landscape. In our studies on pilgrimage as a reviving religious activity, we found the debate on the secularization of Europe too focused on the decline in church membership or attendance and argued that considering other religious practices such as pilgrimage showed a quite opposite picture (Hermkens et al. 2009; Jansen and Notermans 2012). One should therefore allow oneself to hang out in places that do not immediately seem central to the research question. Also one must actively employ and use what elsewhere would be called "wasted time": walking around or visiting people without direct purpose, attending seemingly endless coffee or tea times or drinking sessions.

The often-heralded holistic approach in anthropology requires that a topic should not be demarcated in advance but its permeable boundaries explored. In a similar way, a free-floating approach to people should be maintained throughout the research alongside more formal techniques. In principle anyone can be approached for small talk, in addition to the persons one has planned to interview. This unfocused talking enables not only triangulation to verify certain facts (Denzin 2006) but more importantly a recognition of the multiplicity of voices and the "thickness" of meanings that a gesture, object, or ritual act might have. In order to map a field of meanings, it is all the more important to approach a wide range of people, including such often overlooked categories as children, cleaning ladies, postmen, veiled women, beggars, handicapped persons, or taxi drivers.

Asking such persons with whom one has fleeting conversations in the street, on a bus, or in the market to sign informed consent forms would be absurd. To comply with the ethical principle of informed consent it is usually enough to mention that one is there to write a book, allowing the other to ask for more information if they wish. Tweet-sized summaries of the research project can be composed for this purpose in advance. To be sure, potentially sensitive data require more elaborate ways of securing informed consent and should be handled with care.

Finally, it is important to see small talk as a necessary part of fieldwork and as having all the physical effects of other hard work: fatigue, stress, concentration problems, or feelings of uncertainty or rejection. Short periods of physical or mental withdrawal from the field in order to recover can be planned. The opportunity for serendipity does not come by accident but has to be facilitated in a structured way.

\section{CONCLUSION}

Given the fluid and thin boundary between small talk in fieldwork and in daily life, it does not come as a surprise that the nature and functions of small talk have rarely received systematic attention in written accounts of fieldwork. Also the dominance of positivistic methodology and rhetoric of control or accusations of irrelevance in social science, as well as personal inhibitions and lack of language skills, have led to the underappreciation of small talk as a research technique. 
The examples given here illustrate the importance of small talk in making connections, discovering one another's trustworthiness, and establishing sufficient rapport to enter into deeper or lengthier conversations. Moreover, small talk gives access to information that is difficult to get otherwise but that could be central to understanding culture: rituals that are not on the official program, activities not in line with formal ideologies, double meanings, unspoken antagonisms, muted criticism, cartoons, jokes, or secrets.

Contrary to what the informal and personal character of small talk may suggest, we have proposed that efficient and effective use of small talk can be learned and applied in a structured and systematic way. Apart from training students and oneself to elaborate and systematize normal social graces, this includes a structured inclusion of this focal activity in the field and data collection schedule by applying purposive, free-floating discovery of place, time, topic, and people. Our emphasis on the hard work of small talk by no means excludes the privileged and gratifying character of doing ethnographic fieldwork.

\section{NOTES}

We wish to thank William Christian for his support, Anton Blok for his critical comments and useful references, Kees Versteegh for his valuable linguistic and anthropological suggestions, and the three anonymous $J A R$ reviewers for their encouragement. Joas Wagemakers discussed his conception of doing fieldwork and Miriam Driessen helped to shape some of the issues in an earlier draft of this paper. We are also grateful to Louise Thoonen, Celeste Neelen, and Jan Bransen for their inspirational discussion at Artisa in Greece. This article is an elaboration of a few preliminary ideas presented in a booklet in memory of our colleague Frans Hüsken, who was a kind master of small talk.

1. For a recent and excellent example see Mathews 2011.

2. Also see Herzfeld's notion of productive discomfort (1992:16, 2012:120). To quote him from a very recent chapter on "passionate serendipity": "Our meandering pathways, our intimate and long-term engagement with people who are not particularly famous or obviously talented, our willingness to listen to gossip and find significance in the most trivial of objects and utterances, and our skepticism in the face of mechanical methodologies - these are the sources of that 'productive discomfort,' as I once called it (Herzfeld 1992:16), that enables us to resist an intellectually stultifying closure."

3. James Peacock (1986) briefly explores the resemblances and differences between fieldwork and spying.

4. Ulf Hannerz (2004), having a more positive connotation in mind, introduced the concept of "parachute anthropology," which is aimed at collecting "world stories."

5. See Sharlene Nagy Hesse-Biber (2007) on teaching grounded theory.

\section{REFERENCES CITED}

Augé, Marc, and Jean-Paul Colleyn. 2006. The world of the anthropologist. Oxford: Berg, 2006.

Bernard, H. Russell. 1995. Research methods in anthropology: Qualitative and quantitative approaches, second edition. Walnut Creek, CA: Altamira Press. 
Blok, Anton. 2000. La Maffia di un villaggio siciliano 1860-1960, second edition. Torino: Einaudi.

2005. Serendipity and the art of fieldwork. Etnofoor 18:105-23.

Borneman, John, and Abdellah Hammoudi, eds. 2009. Being there: The fieldwork encounter and the making of truth. Berkeley: University of California Press.

Borofsky, Robert. 2005. Yanomami; The fierce controversy and what can be learned from it. Berkeley: University of California Press.

Boxer, Diana. 2011. The lost art of the good schmooze: Building rapport and defusing conflict in everyday talk. New York: Praeger.

Coupland, Justine, ed. 2000. Small talk. Harlow: Longman.

Denzin, Norman K. 2006. Sociological methods: A source book, fifth edition. Chicago: Aldine/Transaction. (First edition published in 1970)

Driessen, Henk. 1983. Male sociability and rituals of masculinity in rural Andalusia. Anthropological Quarterly 56:125-33.

1992. On the Spanish-Moroccan frontier: A study in ritual, power and ethnicity. Oxford: Berg.

- 1997. "Humour, laughter and the field," in A cultural history of humour. Edited by

J. Bremmer and H. Roodenburg, pp. 222-42. Cambridge: Polity Press.

. 1998. Romancing rapport: The ideology of "friendship" in the field. Folk 40:123-37.

. 2013. "Suspense in retrospective ethnography," in Ethnographies of doubt: Faith and uncertainty in contemporary society. Edited by Mathijs Pelkmans, pp. 149-64. London: I. B. Tauris.

Driessen, Henk, and Willy Jansen. 2013. Staging hyper-masculinity on Maundy Thursday: Christ of the Good Death, the Legion and changing gender practices in Spain. Exchange 42:86-106.

Faubion, James D., and George M. Marcus, eds. 2009. Fieldwork is not what it used to be: Learning anthropology's method in a time of transition. Ithaca, NY: Cornell University Press.

Frake, Charles O. 1964. How to ask for a drink in Subanun. American Anthropologist 66:127-32.

Geertz, Clifford. 1983. Local knowledge: Further essays in interpretive anthropology. New York: Basic Books.

- 1988. Works and lives: The anthropologist as author. Cambridge: Polity Press.

1998. Deep hanging out. The New York Review of Books 45(16):69-72.

. 2000. Available light: Anthropological reflections on philosophical topics. Princeton, NJ: Princeton University Press.

Goffman, Irving. 1990. The presentation of self in everyday life. London: Penguin Books. (Originally published in 1959)

Gottlieb, Alma, ed. 2012. The restless anthropologist: New fieldsites, new visions. Chicago: University of Chicago Press.

Gullestad, Marianne. 2002. Kitchen-table society. Oslo: Scandinavian University Press.

Gumperz, John J., and Dell H. Hymes, eds. 1964. The ethnography of communication. Washington, DC: American Anthropological Association.

Hannerz, Ulf. 2004. Foreign news: Exploring the world of foreign correspondents. Chicago: University of Chicago Press.

. 2010. Anthropology's world: Life in a twenty-first-century discipline. London: Pluto Press.

Hermkens, Anna-Karina, Willy Jansen, and Catrien Notermans, eds. 2009. Moved by Mary: The power of pilgrimage in the modern world. Farnham: Ashgate. 
Herzfeld, Michael. 1992. The social production of indifference: Exploring the symbolic roots of Western bureaucracy. Oxford: Berg.

2012. "Passionate serendipity: From the Acropolis to the Golden Mount," in The restless anthropologist: New fieldsites, new visions. Edited by Alma Gottlieb, pp. 100-23. Chicago: University of Chicago Press.

Holmes, Janet. 2005. "When small talk is a big deal: Sociolinguistic challenges in the workplace," in Second language needs analysis. Edited by Michael H. Long, pp. 344-72. Cambridge: Cambridge University Press.

Hymes, Dell H. 1962. "The ethnography of speaking," in Anthropology and human behavior. Edited by T. Gladwin and W.C. Sturtevant, pp. 15-53. Washington, DC: Anthropological Society of Washington.

- 1972. "On communicative competence,"Sociolinguistics: Selected readings. Edited by J. B. Pride and J. Holmes, pp. 269-93. Harmondsworth: Penguin.

Jansen, Willy. 1987. Women without men: Gender and marginality in an Algerian town. Leiden: Brill.

2000. Sleeping in the womb. Protracted pregnancies in the Maghreb. The Muslim World 90:218-37.

- 2001. "French bread and Algerian wine: Conflicting identities in French Algeria," in Food, drink and identity: Cooking, eating and drinking in Europe since the Middle Ages. Edited by P. Scholliers, pp. 195-218. Oxford: Berg.

Jansen, Willy, and Catrien Notermans, eds. 2012. Gender, nation and religion in European pilgrimage. Farnham: Ashgate.

Jansen, Willy, and Henk Driessen. 2013. Gender dynamics in Andalusian Holy Week brotherhoods. Anthropos 108, in press.

Kulick, Don. 1992. Language shift and cultural reproduction: Socialization, self, and syncretism in a Papua New Guinean village. Cambridge: Cambridge University Press.

Lee, Hellen Morton. 2003. Tongans overseas: Between two shores. Honolulu: University of Hawai'i Press.

Malinowski, Bronislaw. 1946. "The problem of meaning in primitive languages," in The meaning of meaning. Edited by C. K. Ogden and I. A. Richards. London: Kegan Paul and Routledge. (Originally published in 1923)

Marcus, George E. 1995. Ethnography in/of the world system: The emergence of multisited ethnography. Annual Review of Anthropology 24:95-117.

. 2009. "Introduction: Notes toward an ethnographic memoir of supervising graduate research through anthropology's decades of transition," in Fieldwork is not what it used to be: Learning anthropology's method in a time of transition. Edited by James D. Faubion and George M. Marcus, pp. 1-34. Ithaca, NY: Cornell University Press.

Mathews, Gordon. 2011. Ghetto at the center of the world: Chungking Mansions, Hong Kong. Chicago: University of Chicago Press.

Merton, Robert K., and Elinor Barber. 2004. The travels and adventures of serendipity: A study in sociological semantics and the sociology of science. Princeton: Princeton University Press.

Nagy Hesse-Biber, Sharlene. 2007. "Teaching grounded theory," in The Sage handbook of grounded theory. By Anthony Bryant and Kathy Charmaz, pp. 311-39. Los Angeles: Sage Publications.

O'Dell, Tom, and Robert Willim. 2011. Irregular ethnographies: An introduction. Etnologia Europaea 41:5-15. 
Okely, Judith. 2010. "Fieldwork as free association and free passage," in Ethnographic practice in the present. Edited by Marit Melhuus, J. P. Mitchell, and H. Wulff, pp. 28-42. New York: Berghahn Books.

Peacock, James. 1986. The anthropological lens: Harsh light, soft focus. Cambridge: Cambridge University Press.

Pétonnet, Colette. 1982. L'observation flottante: L'exemple d'un cimetière parisien. L'Homme 22:37-47.

Robben, Antonius C. G. M., and Jeffrey A. Sluka, eds. 2007. Ethnographic fieldwork: An anthropological reader. Oxford: Blackwell.

Sluka, Jeffrey A. 2007. "Introduction to Part III: Fieldwork relations and rapport," in Ethnographic fieldwork: An anthropological reader. Edited by Antonius C. G. M. Robben and Jeffrey A. Sluka, pp. 121-26. Oxford: Blackwell.

Stoller, Paul. 2009. The power of the between: An anthropological odyssey. Chicago: University of Chicago Press.

Thomas, Alan, Joanna Chataway, and Marc Wuyts, eds. 1998. Finding out fast: Investigative skills for policy and development. London: Sage, Open University.

Van Maanen, John. 2011. Tales of the field: On writing ethnography, second edition. Chicago: University of Chicago Press. 